\section{Registration of Peanut Germplasm ICGV 88145 and ICGV 89104 Resistant to Seed Infection by Aspergillus flavus}

ICGV 88145 (Reg. no. GP-74, PI 585006) and ICGV 89104 (Reg. no. GP-75, PI 585007) are improved spanish peanut (Arachis hypogaea $\mathrm{L}$. subsp. fastigiata Waldron var. vulgaris Harz) germplasm, bred at the Asia Center of the International Crops Research Institute for the Semi-Arid Tropics (ICRISAT), Patancheru, India. These lines were released in 1993 by the Plant Materials Identification Committee of ICRISAT for their high levels of resistance to natural seed infection by the aflatoxin-producing fungus $A$ spergillus flavus Link:Fr. (3).

The two lines resulted from two single crosses, involving PI 337409 and FESR 12 for ICGV 88145 and ' $\mathrm{J} 11$ ' and U 4-7-5 for ICGV 89104. Pl 337409 is a germplasm line resistant to seed infection (8) and colonization (9) by A. flavus. FESR 12 is a line resistant to rust (caused by Puccinia arachidis Speg.) (1). $\mathrm{J} 11$ is a cultivar widely grown in western and central India and resistant to seed infection and colonization by A. flanis (6). Pl 337409 and $\mathrm{J} 11$ are also resistant to seed infection by A. flavus in Senegal (5, 12 ) and Thailand (11), and are being used in the breeding programs of these countries (10). U 4-7-5 supports only low levels of aflatoxin production (7). ICGV 88145 and ICGV 89104 were bred following the bulk pedigree method. For ICGV 88145, the phenotypically similar $F_{3}$ progenies of $F_{2}$ plants were selected and bulked at harvest, whereas for ICGV 89I04 the selected phenotypically similar $F_{2}$ plants were bulked together at harvest and the first selected bulk was designated as $B_{1}$. The process of bulking the selected phenotypically similar plants was repeated in successive generations until the bulks were phenotypically homogeneous.

The materials were evaluated in the field, for $A$. flavus seed infection (4) in two rainy seasons, under rainfed conditions, and three postrainy seasons, under imposed late-season drought conditions, and for seed colonization $(4,9)$ in one rainy season and two postrainy seasons. The average natural seed infection in ICGV $88145(0.7 \%)$ by $A$. flavis was $50 \%$ that of the best resistant control $\mathrm{J} 11(1.3 \%)$. In ICGV $89104(1.0 \%)$ the average seed infection was $77 \%$ that of $\mathrm{J} 11$. The seed colonization by $A$. flavus under artificial inoculation conditions averaged $22.2 \%$ in ICGV $88145,24.0 \%$ in ICGV $89104,21.4 \%$ in Ah 7223 , and $15.6 \%$ in $\mathrm{J} 11$. The natural aflatoxin contamination in these two lines was zero, compared with $2.1 \mu \mathrm{g} \mathrm{kg}^{-1}$ seed in $\mathrm{J} 11$ and $35.5 \mu \mathrm{g} \mathrm{kg}^{-1}$ seed in the susceptible cultivar JL 24 in the 1992 rainy season. The natural aflatoxin contamination in U 4-7-5 was not estimated.

Both ICGV 88145 and 1CGV 89104 produced higher pod yield than $\mathrm{J} 11$ in several trials conducted across seasons, years, and locations in India. The average pod yield of ICGV 88145 in 14 trials was $2.17 \mathrm{tha}^{-1}(22 \%$ more than $\mathrm{J} 11)$, and the average pod yield of ICGV 89104 in 9 trials was $2.20 \mathrm{ha}^{-1}$ (18\% more than J 11). These lines take 110 to $120 \mathrm{~d}$ to mature in the rainy season at ICRISAT Asia Center.

Both lines have erect growth habit with sequential branching and elliptical light green leaves (2). The number of primary branches ranges from 4 to 5 in ICGV 88I45, and from 4 to 6 in ICGV 89104 , and the number of secondary branches ranges from 0 to 2 in ICGV 88145 and from 3 to 8 in ICGV 89104. The main axes of these lines are approximately $17 \mathrm{~cm}$ in height, with a canopy width of approximately $26 \mathrm{~cm}$.

Pods of ICGV 88145 are mainly two-seeded, medium to large in size ( $33 \mathrm{~mm}$ average length, $13 \mathrm{~mm}$ average breadth) with slight to moderate constriction, and prominently beaked. Pods of ICGV
89104 are mainly two-seeded, medium in size (average $23 \mathrm{~mm}$ length, $11 \mathrm{~mm}$ breadth) with slight constriction, and without beaks. Both lines have tan-colored seeds. The 100 -seed mass is $35 \mathrm{~g}$ for ICGV 88145 and $32 \mathrm{~g}$ for ICGV 89104 . Average meat content is $65 \%$ in ICGV 88145 and $68 \%$ in ICGV 89104 . Oil and protein concentrations are $490 \mathrm{~g} \mathrm{~kg}^{-1}$ and $199 \mathrm{~g} \mathrm{~kg}^{-1}$, respectively, in ICGV 88145 and $534 \mathrm{~g} \mathrm{~kg}^{-1}$ and $182 \mathrm{~g} \mathrm{~kg}^{-1}$ in ICGV 89104.

ICGV 88145 and ICGV 89104 are high-yielding breeding lines and can be cultivated in areas where peanut is exposed to end-ofseason drought conducive to aflatoxin contamination through preharvest seed infection by $A$. flavus. The lines can also be used in germplasm enhancement programs.

Breeder seed of ICGV 88145 and ICGV 89104 is maintained by the Genetic Resources Division at ICRISAT Asia Center. Limited quantities of seed of these lines are available upon request. Seeds of the lines are also deposited with the National Seed Storage Laboratory, 1111 Mason St., Fort Collins, CO 80521-4500.

M. J. V. RAO, H. D. UPADHYAYA, * V. K. MEHAN, S. N. NIGAM, D. MCDONALD, AND N. S. REDDY (I3)

\section{References and Notes}

1. Baily, W.K., E. Stone, K.R. Bromfield, and K.H. Garren. 1973. Notice of release of peanut germplasm with resistance to nust. Virginia Agric. Exp. Stn., Blacksburg, VA, and USDA-ARS, Washington, DC.

2. Intemational Board of Plant Genetic Resources and Intemational Crops Research Institute for the Semi-Arid Tropics. 1992. Descriptors for groundnut. IBPGR, Rome, and ICRISAT, Patanchenu, AP, India

3. Intemational Crops Research Institute for the Semi-Arid Tropics. 1994. Groundnut Elite Germplasm ICGV 88145 and ICGV 89104. ICRISAT Plant Material Description no. 52. ICRISAT, Patanchen, AP, India.

4. Melıan, V.K. 1989. Screening groundnut for resistance to seed invasion by Aspergillus flavus and to aflatoxin production. p. 323-334. In D. McDonald and V.K. Mehan (ed.). Proc. Int. Workshop Aflatoxin Contanination of Groundnut, Patancheru, India. 6-9 Oct. 1987. ICRISAT, Patancheru, AP, India.

5. Mehan, V.K., A. Ba, and J.L. Renard. 1989. Evaluation of groundnut genotypes for field resistance to seed infection by Aspergillus flavus and to aflatoxin contamination: Report of work done during May 1988-April 1989. Paris, France: Institut de Recherches pour les Huiles et Oleagineux, Senegal.

6. Mehan, V.K., D. McDonald, S.N. Nigam, and B. Lalitha. 1981. Groundnut cultivars with seed resistant to invasion by Aspergillus flavus. Oleagineux 36:501-507

7. Mehan, V.K., D. McDonald, and N. Ranuakrishna. 1986. Varietal resistance in peanut to aflatoxin production. Peanut Sci. 13:7-10.

8. Mixon, A.C. 1980 . Comparison of pod and seed screening methods on Aspergillus spp. infection of peanut genotypes. Peanut Sci. 7:1-3.

9. Mixon, A.C., and K.M. Rogers. 1973. Peanut accessions resistant to seed infection by Aspergillus flavus. Agron. J. 65:560-562.

10. Rao, M.J.V., S.N. Nigam, V.K. Mehan, and D. McDonald. 1989. Aspergillus flavus resistance breeding in groundnut: Progress made at 1CRISAT Center. p 345-355. In D. McDonald and V.K. Mehan (ed.). Proc. Int. Workshop Aflatoxin Contamination of Groundnut, Patanchen, India. 6-9 Oct. 1987. ICRISAT, Patanchen, AP, India.

11. Thailand Coordinated Groundnut Improvement Program. 1985. Varjetal improvement. p. 3-92. In Progress report for 1985. TCGIP, Dep. of Agric., Ministry of Agric. and Cooperation, Bangkok.

12. Zambettakis, C., F. Waliyar, A. Bockelee-Morvan, and O. de Pins. 1981. Results of four years of research on resistance of groundnut varieties to Aspergillus flavus. Oleagineux 36:377-385.

13. H.D. Upadhyaya, V.K. Mehan, S.N. Nigam, D. McDonald, and N.S. Reddy, Intemational Crops Research Institute for the Semi-Arid Tropics (ICRISAT), Patancheru P.O., Andhra Pradesh 502 324, India; M.J.V. Rao (former ICRISAT staff), ICI Ltd., Agric. Res. Stn., Begur, Bangalore, Kamataka 560 068, India. ICRISAT Joumal Article no. JA 1658. Registration by CSSA. Accepted 28 Feb. 1995. *Corresponding author (Email: icrisat@cgnet.com).

Published in Crop Sci. 35:1717 (1995). 